\title{
Effectiveness of a Metacognitive Reading Strategies Program for Improving Low Achieving EFL Readers
}

\author{
Nasrah Mahmoud Ismail ${ }^{1} \&$ Tha'er Issa Tawalbeh ${ }^{1}$ \\ ${ }^{1}$ English Language Center, Taif University, Taif, Kingdom of Saudi Arabia \\ Correspondence: Nasrah Mahmoud Ismail, English Language Center, Taif University, P.O. Box 888, 21974 Taif, \\ Kingdom of Saudi Arabia. Tel: 966-501-663-146. E-mail: nasrahme@yahoo.com
}

Received: September 23, 2014 Accepted: November 13, 2014 Online Published: December 30, 2014

doi:10.5539/ies.v8n1p71 URL: http://dx.doi.org/10.5539/ies.v8n1p71

\begin{abstract}
As the training of language learners was a main concern of EFL teachers, this study aimed to assess the effectiveness of metacognitive reading strategies instruction (MRSI) on Taif University EFL students who achieved low results in reading. The final sample of this study was (21) female university students. The sample was divided into two groups; the experimental group, which consisted of (10) girls, and the control group, which consisted of (11) girls. By using the quasi experimental-research methodology, three research objectives were addressed in this study: (a) to examine whether there were significant differences between the experimental group and the control group on the employment of metacognitive reading strategies and reading comprehension post-tests): (b) to explore whether there were significant differences between the mean scores of pre- and post-tests on the English Language reading test: (c) to find out whether there were any significant differences between the mean scores of the post-test and the follow up of the use of metacognitive reading strategies and the English Language reading comprehension test given to the experimental group. Data from pre- and post-test measurements were used to investigate the impact the intervention had on EFL low achievers in reading. Statistical analyses of the data showed that there were statistically significant differences between the experimental group and the control group on the post-test reading comprehension test as well as the reading strategies questionnaire. These showed a significant improvement in the reading skill in the experimental group. They also revealed that there were statistically significant differences between the pre-test and post-test results for the experimental group on the reading comprehension test and the reading strategies. This showed that the experimental group improved in reading skills after the students participated in the program, as seen on the post-test. In the light of these results, the study provided a number of procedural recommendations that may contribute to raising the importance of metacognitive reading strategies training for the students with low achievement in reading.
\end{abstract}

Keywords: EFL non-specialists, reading intervention, low achievers in reading, metacognitive reading strategies, reading comprehension, EFL training program

\section{Introduction}

The status quo of reading comprehension of non-specialist Saudi students

Although English language instruction has been required for intermediate and secondary school students for six years in Saudi Arabia, many university professors and educators have viewed that the English reading level of most college students is far from satisfactory, especially for students who are non-specialists of English. The test results of the midterm and final exams also showed that their reading comprehension is not acceptable. However, college students had much incentive to improve their English skills, as those students study 12 hours weekly.

Reading in a foreign language is very complex and many factors impact the foreign readers' reading processes and their comprehension of texts. These factors include their background knowledge, language proficiency in the L1 and L2, and metacognitive knowledge. Therefore, it takes time for language learners to achieve improvement in reading, especially for learners who learn English in foreign language environment. Since English is neither spoken at home nor in daily communications in Saudi Arabia, the only opportunities EFL students have to learn English occur in English classes. So, the average Saudi college students' reading ability in English usually lags far behind their first language reading competence. According to Eskey (2005), many EFL students may not need to speak English in their daily lives but they need to read it to access the richness of information in English. 
Researchers in metacognition (Jacobs \& Paris, 1987; Zhang \& Seepho, 2012, 2013) have demonstrated that learners' knowledge about what constitutes learning coordinates and directs their thinking and behavior. Thus, if readers are aware of what is involved in the reading process and what is necessary to read effectively, then it is possible for them to take steps to meet the demands of a reading situation. On the other hand, if readers are not aware of, or have misconceptions about, the complexity of a reading task, then they cannot take appropriate action. Many approaches to the teaching of reading have called attention to the importance of EFL/ESL students acquiring metacognitive strategies for comprehension text. Teaching reading strategies has drawn considerable attention from many researchers (Kletzien, 1991; Pressley \& Afflerbach, 1995).

Successful L2 readers engage in a high level of metacognition, or monitoring of their own thinking, during the process of reading. For example, they make predictions, test hypotheses, and monitor their comprehension while extracting meaning from text. Less proficient L2 readers, however, tend to focus heavily on word recognition and word-for-word translation (Auerbach \& Paxton, 1997; Rusciolelli, 1995). As a result, they may employ fewer higher-order thinking processes while reading and may tend to be less metacognitively aware (Rusciolelli, 1995).

Teaching students to read English is a major goal. Research has shown that skills in comprehension and strategies can be taught (Zarrillo, 2007), some students are successful in learning to read English, yet others remain at a low proficiency level throughout their school years. Many different activities are needed to enhance reading. However, poor readers are found not only among EFL learners but also among students reading in their native language (L1). Many adult readers in the United States, for example, have been diagnosed as failing to develop fifth grade level reading skills (Micklos, 1990). These students, often termed "low literate readers" (Gambrell \& Heathington, 1981), have inspired extensive research investigating the reasons for their unsuccessful learning.

\section{Low Reading Achievers}

Literature describes low achievers as young people who have low reading levels (Gambrell \& Heathington, 1981, Micklos, 1990; Hoskyn \& Swanson, 2000, p. 102). They lack the defining attributes of the struggling reader-poor reading comprehension, study skills, word recognition, and reading fluency (R. Vacca \& J. Vacca, 1999). In regards to the importance of reading skills on the other skills, studies show a relationship between amounts read and spelling performance (Stanovich \& West 1989; Polak \& Krashen, 1998) and a positive relationship between reading and writing ability (Lee \& Krashen, 1997). Low achievers had a strong preference for alternative to reading materials, which has implications for the way schools structure reading for adolescents who are struggling readers (Gordon \& Lu, 2008).

In fact, these EFL Saudi students lack proper metacognitive strategies to manage their own reading effectively. Students are uncertain of what metacognitive strategies are and how to use them (Wen, 2003). Poor readers, especially, do not know what methods are efficient for academic reading, nor do they know how to improve their reading ability (Young \& Yoke, 2001). Markedly, in academic reading comprehension, if students lack metacognitive knowledge, they feel puzzled in adopting the appropriate reading methods and reading strategies (Shokrpour \& Fotovatian, 2009). Many researchers have compared the performance of good and poor readers (Mokhtari \& Reichard, 2002; Hsu, 2003; Almasi, 2003) indicating that good readers are more aware of monitoring their comprehension and are also more aware of their strategy use. Poor readers who enhance their awareness of the nature of reading will ultimately become better readers than those who do not (Kinnunen \& Vauras, 1995).

\subsection{Metacognitive Reading Strategies}

Reading is a fundamental skill for learning a foreign language. It is the basis of instructions in all tasks of language learning such as using textbooks, writing tasks, revising and acquiring vocabulary, acquiring grammar, and using computer-assisted language learning programs (Mikulecky, 2008). Anderson (2003) considers reading as "an essential skill which is most important skill to master for most of the learners of English in order to ensure success in learning" (p. 2). Regarding the importance of reading, many researchers recommended different strategies to improve reading comprehension (O'Malley \& Chamot, 1990; Sheorey \& Mokhtari , 2001; Winne \& Nesbit, 2010; Zhang \& Seepho, 2013)

Metacognitive reading strategies indicate learners' knowledge and use of their own cognitive resources (Garner, 1987). Sheorey and Mokhtari (2001), who have conducted research on metacognitive awareness and the use of reading strategies among L2 readers, define metacognitive strategies for reading as "intentional, carefully planned techniques by which learners monitor or manage their reading" (p. 436). McNeil (1987) and Al Faramawy and Radwan $(2004$, p. 203) suggested that metacognition in reading allows readers not only to 
employ particular strategies, but also to become aware of the importance of these strategies and evaluate them. McNeil mentioned that "metacognition refers to one's awareness of what one's purposes for reading are, how to proceed in achieving these purposes, and how to regulate progress through self-checking of comprehension and self-test" (p. 104). And he asserted that metacognitive processes refer to self-knowledge, task knowledge and self monitoring. While Zhang and Seepho (2013) asserted that metacognitive strategies in reading are those strategies designed to increase readers' knowledge of awareness and control, to improve their reading comprehension, and to evaluate whether their attempt at comprehension has been achieved. In addition, Sheorey and Mokhtari (2001) stated that "skilled readers are more able to reflect on and monitor their cognitive processes while reading" (p. 445).

Both L1 and L2 researchers of reading skills emphasized that metacognitive strategies play a significant role in a reader's language learning. O'Malley and Chamot (1990) stressed that "students without metacognitive approaches are essentially learners without direction or opportunity to plan their learning, monitor their progress or review their accomplishments and future directions" (p. 8). Sheorey and Mokhtari (2001) stated that "skilled readers are more able to reflect on and monitor their cognitive processes while reading" (p. 445). Moreover, Zhang and Seepho (2012) pointed out that metacognitive strategies are important for successful second/foreign language readers.

On the whole, much of the research into metacognition in L2 reading revealed that readers' metacognitive strategies are related positively to their success in their L2 reading comprehension and that language proficiency is connected to readers' development of metacognition (Taraban, Rynearson, \& Kerr, 2000; Hong-Nam, Levell, \& Maher, 2014). Hence, it is crucial for L2 readers to be aware of how they should employ reading strategies in planning, regulating and evaluating their own reading processes.

\subsection{Studies on Metacognitive Strategies Training Reading}

Muñiz-Swicegood (1994) explored the effects of metacognitive reading strategy training on bilingual Spanish students. The bilingual Spanish dominant students in this experimental study were taught to use metacognitive reading strategies while reading in Spanish. Post interview results of the Burke Reading Interview, translated into Spanish, showed increases in the frequency of Spanish reading strategies following metacognitive intervention. The study found that significant improvements in the types and frequency of metacognitive strategies that the children were using during their Spanish reading investigation were documented.

Wenden (2001) has carried out metacognitive training with advanced students in Columbia University. In her experiment, she distributes handouts to students which are related to problem-solving reading strategies, and learning language attitudes. After 7 weeks of training, from the results in the questionnaire, most of the subjects thought the training was useless. Wenden explained that the pure metacognitive training has no ideal effectiveness, the subjects thought of it as extra thing in reading; they could not purposefully and actively apply the metacognitive strategies to their reading comprehension.

Salataci and Akyel (2002) investigated the reading strategies of Turkish EFL students in Turkish and English and the possible effects of reading instruction on reading in Turkish and English. The participants consisted of 8 Turkish students enrolled in a pre-intermediate level class of a one-year intensive English course offered at a Turkish-medium technical university. The data came from think-aloud protocols, observation, a background questionnaire, a semi-structured interview and the reading component of the PET (the Preliminary English Test). The results indicated that strategy instruction had a positive effect on both Turkish and English reading strategies and reading comprehension in English.

Moustfa (2004) conducted a study to discover the impact of the use of metacognitive reading strategies on motivation, which results in academic achievement. His study involved 208 secondary school students. He used three questionnaires to measure the metacognitive awareness of reading strategies, motivation and self-worth conception. The findings of his study showed that there was a positive relationship between academic achievement and metacognive awareness of reading strategies. His results also indicated that the most predictive variable of the scores of the academic achievement was metacognitive awareness of reading strategies.

Meng (2004) reported a study of reading strategy training in an ongoing English classroom and investigated the effects of the training on students' reading ability by means of analyzing test results and the questionnaire. Results showed that strategy training was effective in enhancing EFL college students' overall reading proficiency and reading rate. The intervention had significant effect on the improvement of students' abilities to grasp main ideas and to make global and lexical inferences from both given passages and knowledge of the world; however, it had no obvious effect on the improvement of their ability to extract detailed information from the texts 
Karbalaei (2010) made a study to compare between the use of metacognitive reading strategies by EFL and ESL readers. His study involved 189 undergraduate students; among them 96 Iranians as EFL readers and 93 Indians as ESL readers. He used a 30-item questionnaire to measure metacognitive awareness of reading strategies inventory which explore three sets of metacognitive strategies: (1) generalized or global reading strategies, (2) problem-solving strategies, and (3) support reading strategies. The results of his study showed significant differences: Indian students reported using most types of strategies more often than did the Iranian students. He reported that Indians are more interested in using top-down strategies for better comprehension such as summarizing, paraphrasing, note-taking while Iranians are more focused on using bottom-up strategies such as using a dictionary to comprehend meaning.

Karbalaee (2012) carried out a study on Iranian high school EFL 114 male and female students to examine the relationship between reading strategy use and reading achievement. The results revealed that the Iranian EFL high school students reported overall reading strategy use was found to be a predictor of reading comprehension test scores.

\section{Problem Statement}

English as a second/foreign language (ESL/EFL) reading research has focused attention on metacognitive strategy training to improve students' reading comprehension (Wenden, 2001; Al Faramawy, 2004; Karbalaei, 2010). However, the requisite research for such instruction is scarce since little research has been conducted regarding poor readers' concepts about ESL/EFL reading. Two studies have suggested that decoding-oriented concepts correlated with lower performances in reading English in L2 (Carrell, 1989; Devine, 1984).

Reading is an important skill and affects the other language skills, e.g. a student who is a low achiever in reading, is a weak one in understanding the reading text, has a lot of spelling mistakes, poor writing composition, and even his speaking skill can be negatively affected. Moreover, weakness in reading makes the situation difficult in the class, as the student needs to read in front of the class while in the other activities, he can hide himself.

From a personal point of view, which has developed out of our eight-year experience as teachers of EFL, EFL teachers' practices in Saudi universities are far from teaching reading skills and strategies. Rather, EFL teachers spend the time devoted for reading in practicing one skill, "silent reading", and tackling what they believe as comprehension questions". It is because of this huge gap between the world's rapid movement toward teaching reading skills and strategies and the reality of reading instruction in Saudi Arabia, the researchers thought of conducting a study to explore the use of reading strategies among low reading achievement Saudi EFL college learners and how these strategies can help them to increase their level in reading.

Regarding the relationship between the metacognitive reading strategies use and its effect on the readers' reading comprehension, there are few studies touching with the reading strategies of nonnative English speakers, especially for Saudi native speakers (Madkhali, 2005; Mushait, 2004; Al-Nujaidi, 2003; Al-Seweed, 2000). To the researchers' knowledge, most studies that have measured reading strategy use have utilized self-report questionnaires. However, a review of literature revealed that no experimental studies investigated the effectiveness of a program based on metacognitive reading strategies for improving reading achievement for EFL low achievers in reading in Saudi Arabia. Interventions for at-risk students can be expanded by various programs and best practices (Education \& Urban Society, 2003). Determining effective instructional practices for low-achieving, at-risk students is necessary in order to meet the goals that have been set forth by the university.

\section{Study Hypotheses}

This study addressed the following hypotheses:

1) There would be significant differences between the experimental group scores and the control group scores on the post-test of metaconitive reading strategies questionnaire and the English Language reading comprehension test.

2) There would be significant differences between the mean scores of the pre- and post-test of metaconitive reading strategies and the English Language reading comprehension test for the experimental group.

3) There would be no significant differences between the mean scores of the post-test and follow up of Metacognitive reading strategies and the English Language reading comprehension test for the experimental group.

\section{Purposes of the Study}

The purpose of this study was to examine the effect of the metacognitive reading strategies on EFL low achievers in reading. It also aimed to fill the gap in the literature linking theories and practice in the field of 
college EFL low achievers in reading.

\section{Significance of the Study}

1) Making metacognitive reading strategies known to EFL students can help facilitate their positive English reading experience and gain control over their own learning.

2) By keeping reading strategy training, students are encouraged to think about which kinds of strategies they use more often and to perhaps consider adding new strategies or rarely used strategies to their repertoires as they become more aware of other ways to deal with a text.

3) Exploring the use of reading strategies among Saudi EFL learners will provide data that might help in suggesting implications for effective EFL instruction.

4) The results of this study can generate baseline information and provide insights to decision makers in Saudi higher education institutions and in Ministry of Education.

5) The results of this study can help Saudi college-level teachers and students to develop their awareness of effective reading strategies.

6) This study might provide useful information for other developing EFL/ESL studies that have a situation similar to the Saudi one.

\section{Pilot Study Sample}

Forty one female students were randomly drawn from the EFL preparatory non-English major students, second level (Science Stream), for the pilot study. They completed the metacognitive reading strategies questionnaire and the reading comprehension test. Their age ranged from $18-19,(\mathrm{M}=18.682, \mathrm{SD}=0.687)$. Then the data was analyzed to determine the reliability of the instruments.

\subsection{Participants}

One hundred thirty six females participated in this study. To determine who the low achievers in reading were, the researchers followed two steps: (1) according to the mean and Standard deviation in the pre-tests scores ( $\mathrm{M}=$ $8.529, \mathrm{SD}=2.305$ ), so the student who got less than the mean by one standard deviation was considered a low achiever in reading. According this procedure, the students who got six scores and less would be counted as low achievers. (2) The student who scored on the midterm exam below the general average of the reading achievement, that is 3 out 5, was also considered a low achiever. The final sample was 21 students that were divided into two groups; experimental (10 females) and control (11 females). The average age of the students was $(\mathrm{M}=18.714, \mathrm{SD}=.462)$.

\subsection{Table}

Table 1. The comparison between the experimental and the control groups in the study variables and age

\begin{tabular}{|c|c|c|c|c|c|c|}
\hline Reading Strategies Subscales & Group & $\mathrm{N}$ & Mean Rank & $\begin{array}{l}\text { Sum of } \\
\text { Ranks }\end{array}$ & $\begin{array}{c}\text { Mann-Whitney } \\
\text { U }\end{array}$ & Z Sig. \\
\hline \multirow{3}{*}{ Global reading strategies } & Experimental & 10 & 12.25 & 122.50 & \multirow{3}{*}{42.500} & \multirow{3}{*}{$-.8830 .37$} \\
\hline & Control & 11 & 9.86 & 108.50 & & \\
\hline & Total & 21 & & & & \\
\hline \multirow{3}{*}{ Problem-solving strategies } & Experimental & 10 & 10.45 & 104.50 & \multirow{3}{*}{49.500} & \multirow{3}{*}{$-.3900 .696$} \\
\hline & Control & 11 & 11.50 & 126.50 & & \\
\hline & Total & 21 & & & & \\
\hline \multirow{3}{*}{ Support reading strategies } & Experimental & 10 & 11.85 & 118.50 & \multirow{3}{*}{46.500} & \multirow{3}{*}{$-.6020 .547$} \\
\hline & Control & 11 & 10.23 & 112.50 & & \\
\hline & Total & 21 & & & & \\
\hline \multirow{3}{*}{ Reading Strategies Total Score } & Experimental & 10 & 11.20 & 112.00 & \multirow{3}{*}{53.000} & \multirow{3}{*}{$-.1410 .888$} \\
\hline & Control & 11 & 10.82 & 119.00 & & \\
\hline & Total & 21 & & & & \\
\hline
\end{tabular}




\begin{tabular}{ccccccc}
\hline & Experimental & 10 & 10.20 & 102.00 & & \\
Reading comprehension Test Total Score & Control & 11 & 11.73 & 129.00 & & \\
& Total & 21 & & & \\
& Experimental & 10 & 10.85 & 108.50 & & \\
Age & Control & 11 & 11.14 & 122.50 & 53.500 & -.1350 .918 \\
& Total & 21 & & & \\
\hline
\end{tabular}

Table 1 shows that there are no differences between the control and the experimental groups in the pre-tests in reading strategies, reading comprehension test and age. This means that both groups are homogenous.

\section{Instrumentation}

\subsection{The Survey of Reading Strategies (SORS)}

The questionnaire of Reading Strategies (SORS) developed by Mokhtari and Sheorey (2002) measured the metacognitive reading strategies use of L2 readers in the content of reading academic materials. The SORS investigated three kinds of reading strategies: global reading strategies subscale (GLOB subscale) (13 items, 1, 3, $4,6,8,12,15,17,20,21,23,24 \& 27)$, problem-solving strategies subscale (PROP subscale) (8 items, $9,7,11,14,16,19,25 \& 28)$, and support reading strategies subscale (SUP subscale) (9 items, 2, 5, 10, 13, 18, 22, $26,29 \& 30$ ). This survey will be used in this study to investigate the student's use of metacognitive reading strategies.

\subsection{Psychometric Conditions of the Reading Strategies in Current Research}

Based on the item-total correlation one item, ten items $(8,15,20,27,11,19,28,10,13,26)$ were deleted from the questionnaire, so the questionnaire was 20 items instead of 30. The first subscale (GLOB subscale) includes (9 items, 1, 3, 4, 6, 9, 12, 14, $16 \&$ 17). The second problem-solving strategies subscale includes ( 5 items, 7, 8 , $10,11 \& 18$ ). The third subscale (support reading strategies) includes (6 items, 2, 5, 13, 15, $19 \& 20$ ) (See Appendix A). To get reliable and valid answers from the students, and because the students are non-English specialists, the researchers translated the Metacognitive strategies questionnaire from English into Arabic. It was revised and evaluated by experts in the field (See Appendix B).

\subsection{Item Validity and Internal Consistency for Metacognitive Reading Strategies Questionnaire}

The corrected item-total correlation ranged from 0.37 to $0.63(\mathrm{p}<0.01)$, suggesting adequate item validity. The corrected item-Subscale 1 (Global reading strategies) correlation ranged from 0.33 to 0.59 ( $p<0.01$ ), for Subscale 2 (problem-solving strategies) the correlation ranged from 0.59 to $0.80(\mathrm{p}<0.01)$, and for Subscale 3 (support reading strategies) the correlation ranged from 0.36 to $0.77(\mathrm{p}<0.01)$, suggesting adequate item validity On the other hand, the correlation between factors ranged from 0.39 to 0.60 and between factors and the total score ranged from 0.68 to $0.87(\mathrm{p}<0.05$ to $\mathrm{p}<0.01$ ). The internal consistency was high for the total questionnaire $(\alpha=0.81)$, as well as for subscale $1(\alpha=0.70)$, subscale $2(\alpha=0.54)$, subscale $3(\alpha=0.63)$. The mean Total score was $67.902(\mathrm{SD}=11.989)$. The mean for subscale 1 was $28.79(\mathrm{SD}=6.06)$, for subscale 2 was $18.80(\mathrm{SD}=3.79)$, for subscale 3 was $20.31(\mathrm{SD}=4.92)$.

\subsection{Psychometric Conditions of the Reading Comprehension Test in the Current Research}

The test was prepared by the researchers. It consisted of two passages and 20 multiple choice questions. Each passage was followed by 10 questions. The total mark of the test was 20 (See Appendix C).

\subsection{Item Validity and Internal Consistency for the Reading Comprehension Test}

The Pearson Correlation between the reading test and the students' GPA (grade point Average) was 0.71, suggesting adequate validity. In addition, the discrimination index for each item indicates that the validity of each item is high. The internal consistency is high for the total test $(\alpha=0.75)$. 
8.6 Table

Table 2. Easiness, variance and discrimination indices for reading comprehension test

\begin{tabular}{llllllll}
\hline $\begin{array}{l}\text { No. of } \\
\text { questions }\end{array}$ & $\begin{array}{l}\text { Easiness } \\
\text { index }\end{array}$ & Variance & $\begin{array}{l}\text { Discrimination } \\
\text { index }\end{array}$ & $\begin{array}{l}\text { No. of } \\
\text { questions }\end{array}$ & $\begin{array}{l}\text { Easiness } \\
\text { index }\end{array}$ & Variance & $\begin{array}{l}\text { Discrimination } \\
\text { index }\end{array}$ \\
\hline 1. & 0.71 & 0.21 & 0.27 & 11 & 0.63 & 0.23 & 0.64 \\
2. & 0.78 & 0.17 & 0.36 & 12 & 0.46 & 0.25 & 0.55 \\
3. & 0.32 & 0.16 & 0.46 & 13 & 0.51 & 0.25 & 0.73 \\
4. & 0.68 & 0.22 & 0.73 & 14 & 0.56 & 0.25 & 0.64 \\
5 & 0.66 & 0.22 & 0.64 & 15 & 0.51 & 0.25 & 1.00 \\
6 & 0.85 & 0.13 & 0.32 & 16 & 0.85 & 0.13 & 0.36 \\
7 & 0.36 & 0.20 & 0.27 & 17 & 0.93 & 0.17 & 0.00 \\
8 & 0.100 & 0.15 & 0.09 & 18 & 0.93 & 0.17 & 0.00 \\
9 & 0.78 & 0.17 & 0.36 & 19 & 0.80 & 0.16 & 0.36 \\
10 & 0.32 & 0.20 & 0.36 & 20 & 0.83 & 0.22 & 0.45 \\
\hline
\end{tabular}

The suitable range for easiness index is from 0.15 to 0.85 (Alaam, 2011, p. 114). As shown in Table 2, all the questions are within this range. But based on the discrimination index, three items were omitted (items numbers $8,17 \& 18$ ), as their discrimination indices were below 0.2 . They were weak items (Alaam, 2011, p. 116). Thus the reading comprehension test became 17 items instead of 20. Seventeen points were devoted for the whole test, one mark for each correct answer and correspondingly a wrong answer got zero. Finally, the marks on the test were from 0 to 17 . The students were given 30 minutes to complete the reading test.

\section{Experimental Procedures of the Reading Strategies Program}

The structured reading strategies training program included an experimental group of ten students. The program took place in the second semester of 2014. The training program consisted of 20 sessions, two sessions per week for 10 weeks. The two groups, the control and the experimental groups, were instructed by the same teacher. The control group practiced reading comprehension without using the strategy training program. Participants in the control group were not provided with any kind of pre-reading activities (e.g., reading strategies pre-teaching). For the experimental group, the researcher started each session with some reading strategies, such as Global reading strategies, Problem-solving strategies and Support reading to make the students aware of how to read and to plan what they are going to do during the reading session. Before reading each day, the researcher chose some different reading strategies to discuss with the students before the program session to help them to understand the reading passage. The researcher asked the students to read the reading passage. Then students were given time to answer all reading comprehension questions. After that, the teacher gave them feedback on their tasks. Finally, the reading comprehension post-test was administered to both groups in the same manner as the pre-test. The program was evaluated through the pre-tests and the post-tests, through a comparison between the experimental group and the control group scores, and also through the follow up in developing the metacognitive reading strategies one month after concluding the program. This researcher concurs with Cooper and Kiger (2006), who said that reading intervention should give the students more instruction, not less instruction, for the program to work to the students' best interest. 


\section{Results}

Table 3. The Differences between the experimental and control group on the metacognitive reading strategies and reading comprehension test on post-tests

\begin{tabular}{|c|c|c|c|c|c|c|c|}
\hline Reading Strategies Subscales & Group & $\mathrm{N}$ & Mean Rank & Sum of Ranks & Mann-Whitney U & $\mathrm{Z}$ & Sig. \\
\hline \multirow{3}{*}{ Global reading strategies } & Experimental & 10 & 14.60 & 146.00 & \multirow{3}{*}{19.000} & \multirow{3}{*}{-2.546} & \multirow{3}{*}{0.011} \\
\hline & Control & 11 & 7.73 & 85.00 & & & \\
\hline & Total & 21 & & & & & \\
\hline \multirow{3}{*}{ Problem-solving strategies } & Experimental & 10 & 14.15 & 141.50 & \multirow{3}{*}{23.500} & \multirow{3}{*}{-2.249} & \multirow{3}{*}{0.025} \\
\hline & Control & 11 & 8.14 & 89.50 & & & \\
\hline & Total & 21 & & & & & \\
\hline \multirow{3}{*}{ Support reading strategies } & Experimental & 10 & 15.85 & 158.50 & \multirow{3}{*}{6.500} & \multirow{3}{*}{-3.428} & \multirow{3}{*}{0.001} \\
\hline & Control & 11 & 6.59 & 72.50 & & & \\
\hline & Total & 21 & & & & & \\
\hline \multirow{3}{*}{ Reading Strategies Total Score } & Experimental & 10 & 14.35 & 143.50 & \multirow{3}{*}{21.500} & \multirow{3}{*}{-2.362} & \multirow{3}{*}{0.018} \\
\hline & Control & 11 & 7.95 & 87.50 & & & \\
\hline & Total & 21 & & & & & \\
\hline \multirow{3}{*}{ Reading comprehension Test Total Score } & Experimental & 10 & 15.65 & 156.50 & \multirow{3}{*}{8.500} & \multirow{3}{*}{-3.314} & \multirow{3}{*}{.001} \\
\hline & Control & 11 & 6.77 & 74.50 & & & \\
\hline & Total & 21 & & & & & \\
\hline
\end{tabular}

As Table 3 shows, there are significant differences between the experimental group and the control group in metacognitive reading strategies and in reading comprehension post-tests which confirmed that the first hypothesis was correct. That is, the mean of the experimental group was higher than that of the control group in the reading strategies with a $Z$ value $=-2.362, p<0.05$ ). The researchers presume that the positive results of the experimental group are due to the effects of the program which includes a lot of reading activities that the students shared with each other and it was suitable to the students' level.

Table 4. Means and standard deviation for the pre and post-tests of reading strategies and the English language reading comprehension test for the experimental group

\begin{tabular}{llllll}
\hline & Pre-test & & \multicolumn{3}{l}{ Post-test } \\
\hline Reading Strategies Subscales & $\mathrm{N}$ & Mean & Std. D. & Mean & Std. D. \\
Global reading strategies & 10 & 25.600 & 5.481 & 32.100 & 3.785 \\
Problem-solving strategies & 10 & 14.900 & 4.202 & 19.600 & 2.591 \\
Support reading strategies & 10 & 18.800 & 6.125 & 24.300 & 3.020 \\
Reading Strategies total Score & 10 & 60.600 & 16.406 & 72.100 & 9.183 \\
Reading Comprehension Test Total Score & 10 & 5.900 & 1.524 & 14.700 & 2.541 \\
\hline
\end{tabular}


Table 5. The differences between the ranks scores of the pre and post-tests of reading strategies and the English language reading comprehension test for the experimental group

\begin{tabular}{|c|c|c|c|c|c|c|c|}
\hline $\begin{array}{c}\text { Reading Strategies } \\
\text { Subscales }\end{array}$ & Pre-test and post-test & & $\mathrm{N}$ & Mean Rank & $\begin{array}{l}\text { Sum of } \\
\text { Ranks }\end{array}$ & $\mathrm{Z}$ & Sig. \\
\hline \multirow{4}{*}{ Global reading strategies } & \multirow{4}{*}{$\begin{array}{l}\text { Post-test } \\
\text { Pre-test }\end{array}$} & Negative Ranks & 0 & .00 & .00 & \multirow{4}{*}{-2.807} & \multirow{4}{*}{.005} \\
\hline & & Positive Ranks & 10 & 5.50 & 55.00 & & \\
\hline & & Ties & 0 & & & & \\
\hline & & Total & 10 & & & & \\
\hline \multirow{4}{*}{ Problem-solving strategies } & \multirow{4}{*}{ Pre-test } & Negative Ranks & 0 & .00 & .00 & \multirow{4}{*}{-2.807} & \multirow{4}{*}{.005} \\
\hline & & Positive Ranks & 10 & 5.50 & 55.00 & & \\
\hline & & Ties & 0 & & & & \\
\hline & & Total & 10 & & & & \\
\hline \multirow{4}{*}{ Support reading strategies } & & Negative Ranks & 1 & 6.00 & 6.00 & \multirow{4}{*}{-2.194} & \multirow{4}{*}{0.028} \\
\hline & Pos-test & Positive Ranks & 9 & 5.44 & 49.00 & & \\
\hline & Pre-test & Ties & 0 & & & & \\
\hline & & Total & 10 & & & & \\
\hline \multirow{4}{*}{$\begin{array}{c}\text { Reading Strategies total } \\
\text { Score strategies }\end{array}$} & & Negative Ranks & 1 & 4.50 & 4.50 & \multirow{4}{*}{-2.347} & \multirow{4}{*}{0.019} \\
\hline & Pos-test & Positive Ranks & 9 & 5.61 & 50.50 & & \\
\hline & Pre-test & Ties & 0 & & & & \\
\hline & & Total & 10 & & & & \\
\hline \multirow{4}{*}{$\begin{array}{c}\text { Reading Comprehension } \\
\text { Test Total Score }\end{array}$} & & Negative Ranks & 0 & .00 & .00 & \multirow{4}{*}{-2.812} & \multirow{4}{*}{.005} \\
\hline & Pos-test & Positive Ranks & 10 & 5.50 & 55.00 & & \\
\hline & Pre-test & Ties & 0 & & & & \\
\hline & & Total & 10 & & & & \\
\hline
\end{tabular}

In Table 5, the results showed that the differences between the ranks scores of the pre and post-tests of reading strategies subscales and the English Language reading test total score are in favor of the experimental group ( $Z$ $(10)=-2.347, p<0.05)$. These differences can be explained by the importance of the reading program and the importance of its training, as well as showing the importance of the teaching style and additional materials that the main researcher introduced during the program.

Table 6. Means and standard deviation for the post-tests and follow up of reading strategies and the English language reading comprehension test for the experimental group

\begin{tabular}{lccccc}
\hline & $\mathrm{N}$ & \multicolumn{2}{c}{ Post-tests } & \multicolumn{2}{c}{ follow up } \\
\hline Reading Strategies & $\mathrm{N}$ & Mean & Std. D. & Mean & Std. D. \\
Global reading strategies & 10 & 32.100 & 3.785 & 31.200 & 4.492 \\
problem-solving strategies & 10 & 19.600 & 2.591 & 18.200 & 3.393 \\
Support reading strategies & 10 & 24.300 & 3.020 & 24.300 & 3.020 \\
Reading Strategies total Score & 10 & 72.100 & 9.183 & 70.000 & 11.557 \\
Reading comprehension Test total score & 10 & 14.700 & 2.541 & 13.912 & 2.321 \\
\hline
\end{tabular}


Table 7. The Differences between the ranks scores of the post-test and follow up of reading strategies and reading comprehension test

\begin{tabular}{|c|c|c|c|c|c|c|c|}
\hline Reading Strategies & & & $\mathrm{N}$ & Mean Rank & Sum of Ranks & $\mathrm{Z}$ & Sig. \\
\hline \multirow{4}{*}{ Global reading strategies } & \multirow{4}{*}{ Follow up-Post } & Negative Ranks & 2 & 1.50 & 3.00 & \multirow{4}{*}{-1.342} & \multirow{4}{*}{0.180} \\
\hline & & Positive Ranks & 0 & .00 & .00 & & \\
\hline & & Ties & 8 & & & & \\
\hline & & Total & 10 & & & & \\
\hline \multirow{4}{*}{ Problem-solving strategies } & \multirow{4}{*}{ Follow up-Post } & Negative Ranks & 4 & 2.50 & 10.00 & \multirow{4}{*}{-1.826} & \multirow{4}{*}{0.068} \\
\hline & & Positive Ranks & 0 & .00 & .00 & & \\
\hline & & Ties & 6 & & & & \\
\hline & & Total & 10 & & & & \\
\hline \multirow{4}{*}{ Support reading strategies } & \multirow{4}{*}{ Follow up-Post } & Negative Ranks & 0 & .00 & .00 & \multirow{4}{*}{0.000} & \multirow{4}{*}{1.000} \\
\hline & & Positive Ranks & 0 & .00 & .00 & & \\
\hline & & Ties & 10 & & & & \\
\hline & & Total & 10 & & & & \\
\hline \multirow{4}{*}{ Reading Strategies total Score } & \multirow{4}{*}{ Follow up-Post } & Negative Ranks & 2 & 1.50 & 3.00 & \multirow{4}{*}{-1.342} & \multirow{4}{*}{0.180} \\
\hline & & Positive Ranks & 0 & .00 & .00 & & \\
\hline & & Ties & 8 & & & & \\
\hline & & Total & 10 & & & & \\
\hline
\end{tabular}

Table 7 showed that there are no statistically significant differences between the mean scores of the first post-test and the second (follow up) post-test that was given about month after the first post-test on the reading strategies and the reading test. The results made it obvious that the effects of the reading strategies training program should continue and it should be of great value to future students.

\section{Discussion}

The main purpose of the present study was to investigate the effect of a program based on metacognitive reading strategies to develop the reading skill of second level college students who have a low achievement in reading. With regard to the first research hypothesis results, the results of the present study proved that there were statistically significant differences between the mean scores of the experimental group in each of the pre and post-test mean scores and the control group in favor of the experimental group. They confirmed the correction of the first hypothesis; the mean of the experimental group was higher than the control group. This result is consistent with the results of many studies (e.g., Auerbach \& Paxton, 1997; Rusciolelli, 1995; Al Faramaway, 2004; Huang \& Newbern, 2012) which confirmed that metacognition is critical to effective reading in an L2.

With regard to the second hypothesis was that there would be significant differences between the mean scores of the pre and post-test of metaconitive reading strategies and the English language reading comprehension test for the experimental group. This can be interpreted as the role of reading strategy's usefulness in helping readers achieve better comprehension when reading a passage, which is emphasized in the realm of EFL (Macaro, 2003; Pressley \& Harris, 2006; Sinatra, Brown, \& Reynolds, 2002,). The use of a reading strategy can help readers deal with the problems which arise while reading in a foreign language, and consequently, individuals' reading comprehension can be improved. The results of a number of experimental studies (e.g., Wenden, 2001; Cubukcu, 2008; Karbalaei, 2010; Huang \& Newbern, 2012) have indicated significant gains in reading proficiency of adult ESL learners following metacognitive strategy training. Notably, in all of the aforementioned studies, the experimental group significantly outperformed the control group on objective assessments which measured reading proficiency gains. Moreover, Anderson (2003) asserted that reading develops gradually as the reader does not become fluent suddenly or immediately following a reading course.

With regard to the third hypothesis was that there would be no significant differences between the mean scores of the post-test and follow up of Metacognitive reading strategies and the English Language reading comprehension test for the experimental group. The data showed that the effects of the reading training program 
continued and had a great benefit to EFL students. This finding agrees with Shinn (1998), and Gordon and Lu (2008). This study can be seen as further evidence to the idea that learners should be provided with a training program to train them how to read and how to choose the best strategies to help their reading. Successful reading programs should provide activities that challenge the students (Meng, 2004; Zarillo, 2007).

\section{Conclusion}

In summary, this study was carried out in part because the researchers were unable to find studies which examine the effectiveness of metacognitive reading strategies on the low reading achievers by experiment, especially in Saudi Arabia. The results have implications for EFL teachers, which should motivate them to provide their learners with reading strategy training which can lead to better achievement in reading comprehension. Thus, if readers are aware of what is involved in the reading process and what is necessary to read effectively, then it is possible for them to take steps to meet the demands of the reading situation. The results of the current study have implications for language learners, encouraging them to become more conscious of their own strategy use. The questionnaire in Appendix A is composed of twenty items that are actually teaching strategies made into the form of questions for the students. These strategies can be used by the teacher to make their students aware that reading strategies are powerful reading tools. Finally, the researchers suggest that future research focus on the development of the effectiveness of metacognitive reading strategy programs for primary, middle and high school students.

\section{References}

Al Faramaway, H. A. (2004). The Training of Primary School Students on Metareading Skills (Suggested Instrumental Mode of Metareadingl). Egyptian Journal of Psychological Studies, 14(42), 145-176.

Alaam, S. (2011). Educational and Psychological tests and Measurements (2nd ed.). Amman, Dar Al Fikr.

Almasi, J. F. (2003). Teaching Strategies Processes in Reading. New York: Guilford Press.

Al-Nujaidi, A. (2003). The relationship between vocabulary size, reading strategies, and reading comprehension of EFL learners in Saudi Arabia (Unpublished doctoral dissertation). Oklahoma State University, Stillwater.

Al-Seweed, M. (2000). The effects of proficiency and training on the word-solving strategies of Arab EFL readers (Unpublished doctoral dissertation). University of Essex, UK.

Anderson, N. J. (2003). Scrolling, clicking, and reading English: Online Reading strategies in a second/foreign language. The Reading Matrix, 3(3), 1-33.

Auerbach, E., \& Paxton, D. (1997). "It's not the English thing": Bringing reading research into the ESL classroom. TESOL Quarterly, 31, 237-261. http://dx.doi.org/10.2307/3588046

Carrell, P. L. (1989). Metacognition Awareness and Second Language Reading. Modern Language Journal, 73(2), 121-134. http://dx.doi.org/10.1111/j.1540-4781.1989.tb02534.x

Cooper, J., \& Kiger, N. (2006). Literacy: Helping children construct meaning (6th ed.). Boston: Houghton Mifflin.

Cubukcu, F. (2008). Enhancing vocabulary development and reading comprehension through metacognitive strategies. Issues in Educational Research, 18(1).

Devine, J. (984). ESL readers' internalized models of the reading process. In J. Handscombe, R. Orem, \& B. Taylor (Eds.), On TESOL'S3 (pp. 95-108). Washington, DC: TESOL.

Education \& Urban Society. (2003). Literacy and learning. Retrieved July 5, 2006, from http://eus.sagepub.com/

Eskey, D. E. (2005). Reading in a second language. In E. Hinkel (Ed.), Handbook of research in second lan-guage teaching and learning (pp. 563-580). Mahwah, NJ: Lawrence Erlbaum Associates.

Gambrell, L. B., \& Heathington, B. S. (1981). Adult disabled readers' metacognitive awareness about reading tasks and strategies. Journal of Reading Behavior, 13, 215-222.

Garner, R. (1987). Metacognition and reading comprehension. Norwood, NJ: Ablex.

Gordon, C., \& Lu, Y. (2008). “I hate to Read-Or Do I?" Low Achievers and Their Reading. Research Journal of the American Association of School Librarians, 11, 1-15.

Hong-Nam, K., Levell, A. G., \& Maher, S. (2014). The Relationships Among Reported Strategy Use, Metacognitive Awareness, and Reading Achievement of High School Students. Reading Psychology, 35, 762-790. http://dx.doi.org/10.1080/02702711.2013.807900 
Hoskyn, M., \& Swanson L. E. (2000). Cognitive processing of low achievers and children with reading disabilities: A selective meta-analytic review of the published literature. School Psychology Review, 29(1), 102-119.

Hsu, L. R. (2003). A Study of Relationships between feeling of Knowing about English Reading strategy Use and Reading Comprehension of Taiwanese College Students. National Changhua University of Education.

Huang, J., \& Newbern, C. (2012). The effects of metacognitive reading strategy instruction on reading performance of adult ESL learners with limited English and literacy skills. Journal of Research and Practice for Adult Literacy, Secondary, and Basic Education, 1(2), 66-77.

Jacobs, J. E., \& Paris, S. G. (1987). Children's metacognition about reading: Issues in definition, measurement, $\begin{array}{llll}\text { and instruction. } & \text { Educational } & \text { Psychologist, } & \text { 22(3\&4), }\end{array}$ http://dx.doi.org/10.1080/00461520.1987.9653052

Karbalaee, K. S. (2012). Does reading strategy use predict and correlate with reading achievement of EFL learners? International Journal of Research Studies in Language Learning, 2(2), 29-38.

Karbalaei, A. (2010). A Comparison of the Metacognitive Reading Strategies Used by EFL and ESL Readers. The Reading Matrix, 2(10), 165-180.

Kinnunen, R., \& Vauras, M. (1995). Comprehension monitoring and the level of comprehension in high- and low-achieving primary school children's reading. Learning and Instruction, 5(2), $143-165$. http://dx.doi.org/10.1016/0959-4752(95)00009-R

Kletzien, S. B. (1991). Strategies Use by Good and Poor Comprehenders Read Expository Text of Differing levels. Reading Research Quarterly, 26(1), 67-86. http://dx.doi.org/10.2307/747732

Lee, S. Y., \& Krashen, S. D. (1997). Writing apprehension in Chinese as a first language. ITL: Review of Applied Linguistics, 115-116, 27-37.

Macaro, E. (2003). Teaching and learning a second language. London: Continuum.

Madkhali, S. (2005). Effects of training ESL Saudi female students on some reading strategies (Unpublished dissertation). Ball State University, Muncie.

McNeil, J. (1987). Reading Comprehension (2nd ed.). Glenview, IL: Scott, Foresman and Company.

Meng, Y. (2004). A statistical research of college English reading strategy training. Foreign Languages and Their Teaching, 2, 24-27.

Micklos. (1990). NAEP results show little change in reading skills. Reading Today, 7, 1-8.

Mikulecky, P. S. (2008). Teaching Reading in a Second Language. Pearson Education, 0-13-503146-X.

Mokhtari, K., \& Reichard, C. A. (2002). Assessing students' Metacognitive Awareness of Reading Strategies. Journal of Educational Psychology, 94(2), 249-259. http://dx.doi.org/10.1037/0022-0663.94.2.249

Mokhtari, K., \& Sheorey, R. (2002). Measuring ESL students' reading strategies. Journal of Developmental Education, 25(3), 2-10.

Moustfa, A. M. (2004). The Impact Metacognitive Reading Strategies and Motivation for Scholastic Achievement and Self-Worth protection on Secondary Students' Academic Achievement. Egyptian Journal of Psychological Studies, 14(42), 271-370.

Muñiz-Swicegood, M. (1994). The effects of metacognitive reading strategy training on the reading performance and student reading analysis strategies of third grade bilingual students. Bilingual Research Journal, 18, $1-2$.

Mushait, S. (2004). The relationship of $L 1$ reading and L2 language proficiency with the L2 reading comprehension and strategies of Saudi EFL university students (Unpublished doctoral dissertation). University of Essex, UK.

O’Malley, M., \& Chamot, A. (1990). Learning strategies in second language acquisition. New York: Cambridge University Press. http://dx.doi.org/10.1017/CBO9781139524490

Polak, K., \& Krashen, S. (1998). Do we need to teach spelling? The relationship between spelling and vocabulary and voluntary reading among community college ESL students. TESOL Quarterly, 22, 141-146. http://dx.doi.org/10.2307/3587067

Pressley, M., \& Afflerbach, P. (1995). Verbal Protocols of Reading: The Nature of Constructively Responsive 
reading. New Jersey: Lawrence Erlbaum Associates.

Pressley, M., \& Harris, S. (2006). Cognitive strategies instruction: From basic research to classroom instruction. In P. Alexander, \& P. Winn (Eds.), Handbook of educational psychology (2nd ed., pp. 265-286). Mahwah, NJ: Lawrence Erlbaum.

Rusciolelli, J. (1995). Student responses to reading strategies instruction. Foreign Language Annals, 28(2), 262-273. http://dx.doi.org/10.1111/j.1944-9720.1995.tb00791.x

Salataci, R., \& Akyel, A. (2002). Possible effects of strategy instruction on L1 and L2 reading. Reading in a Foreign Language, 14, 1-17.

Sheorey, R., \& Mokhtari, K. (2001). Differences in Metacognition Awareness of Reading Strategies Among native and Non-native readers. System, 29(4), 431-449. http://dx.doi.org/10.1016/S0346-251X(01)00039-2

Shinn, F. (1998). Implementing free voluntary reading with ESL middle school students-improvement in attitudes toward reading and test scores. In R. Constantino (Ed.), Literacy, access, and libraries among the language minority population (pp. 225-234). Lanham, Md.: Scarecrow.

Shokrpour, N., \& Fotovatian, S. (2009). The effects of consciousness raising on metacognitive strategies on EFL students' reading comprehension. ITL International Journal of Applied Linguistics, 3, 221-245.

Sinatra, G., Brown, K., \& Reynolds, R. (2002). Implications of cognitive resource allocation for comprehension strategies instruction. In C. Block, \& M. Pressley (Eds.), Comprehension instruction: Research-based best practices (pp. 62-76). New York: Guilford Press.

Stanovich, K., \& West, R. (1989). Exposure to print and orthographic processing. Reading Research Quarterly, 24, 402-433. http://dx.doi.org/10.2307/747605

Taraban, R., Rynearson, K., \& Kerr, M. S. (2000). Metacognition and Freshman Academic Performance. Journal of Development Education, 24(1), 12-20.

Vacca, R. T., \& Vacca, J. (1999). Content area reading. New York: Longman.

Wen, Q. F. (2003). The successful way of learning English. Shanghai: Shanghai Foreign Language Education Press.

Wenden, A. L. (2001). Metacognitive knowledge in SLA: The neglected variable. In M. P. Breen (Ed.), Learner contributions to language learning: New directions in research (pp. 44-46). Harlow/Essex, UK: Pearson.

Winne, P. H., \& Nesbit, J. C. (2010). The psychology of academic achievement.

Young, C., \& Yoke, S. F. (2001). Learner diaries as a tool to heighten Chinese students' metacognitive awareness of English learning. Reflections on English Language Teaching, 1, 125-138.

Zarillo, J. (2007). Are you prepared to teach reading: A practical guide for self-assessment. Upper Saddle River, NJ: Pearson Merrill Prentice Hall.

Zhang, L., \& Seepho, S. (2012). Effects of MST (Metacognitive Strategy Training) on Academic Reading Comprehension of Chinese EFL Students. US-China Foreign Language, 10 (2), 933-943.

Zhang, L., \& Seepho, S. (2013). Metacognitive Strategy Use and Academic Reading Achievement: Insights from a Chinese Context. Electronic Journal of Foreign Language Teaching, 10(1), 54-69.

\section{Appendix A}

Survey of Reading Strategies (SORS)

Dear student,

The purpose of this survey is to collect information about the various strategies you use when you read school-related academic materials in English (e.g., reading textbooks for homework or examinations, reading journal articles, etc.). Each statement has five options; after reading each statement makes a tick $(\sqrt{ })$ under the option which applies to you. Note that there is no right or wrong responses to any of the items on this survey. 


\begin{tabular}{|c|c|c|c|c|c|c|}
\hline & Items & $\dot{\bar{d}}$ & 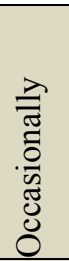 & 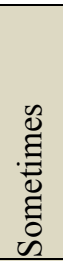 & 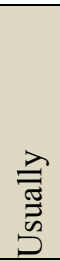 & $\underset{\frac{\pi}{2}}{\stackrel{\infty}{2}}$ \\
\hline & \multicolumn{6}{|l|}{ Global reading strategies } \\
\hline 1 & I have a purpose in mind when I read. & & & & & \\
\hline 3 & I think about what I know to help me understand what I read. & & & & & \\
\hline 4 & I take an overall view of the next to see what it is about before reading it. & & & & & \\
\hline 6 & I think about whether the content of the text fits my reading purpose. & & & & & \\
\hline 9 & When reading, I decide what to read closely and what to ignore. & & & & & \\
\hline 12 & I use context clues to help me better understand what I am reading. & & & & & \\
\hline 14 & I critically analyze and evaluate the information presented in the text. & & & & & \\
\hline 16 & I check my understanding when I come across new information. & & & & & \\
\hline 17 & I try to guess what the content of the text is about when I read. & & & & & \\
\hline \multicolumn{7}{|c|}{ Problem-solving strategies } \\
\hline 7 & $\begin{array}{l}\text { I read slowly and carefully to make sure understand what I am } \\
\text { reading. }\end{array}$ & & & & & \\
\hline 8 & I try to get back on track when I lose concentration. & & & & & \\
\hline 10 & $\begin{array}{l}\text { When text becomes difficult, I pay closer attention to what I am } \\
\text { reading. }\end{array}$ & & & & & \\
\hline 11 & I stop from time to time and think about what I am reading. & & & & & \\
\hline 18 & $\begin{array}{l}\text { When text becomes difficult, I re-read it to increase my } \\
\text { understanding. }\end{array}$ & & & & & \\
\hline \multicolumn{7}{|c|}{ Support reading strategies } \\
\hline 2 & I take notes while reading to help me understand what I read. & & & & & \\
\hline 5 & $\begin{array}{l}\text { When text becomes difficult, I read aloud to help me understand what } \\
\text { I read. }\end{array}$ & & & & & \\
\hline 13 & $\begin{array}{l}\text { I paraphrase (restate ideas in my own words) to better understand } \\
\text { what I read. }\end{array}$ & & & & & \\
\hline 15 & I go back and forth in the text to find relationships among ideas in it. & & & & & \\
\hline 19 & When reading, I translate from English into Arabic. & & & & & \\
\hline 20 & When reading, I think about information in both English and Arabic. & & & & & \\
\hline
\end{tabular}

\section{Appendix B}

Arabic Version of Reading Strategies (SORS)

عزيزتي الطالبة

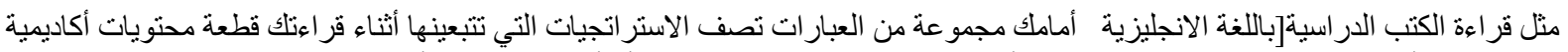

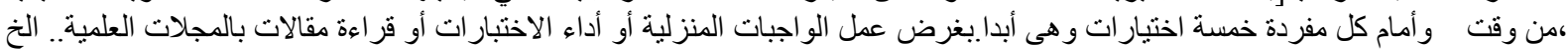

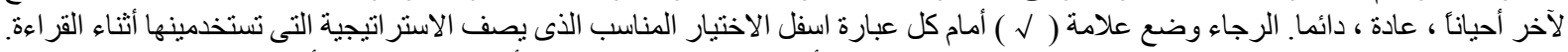

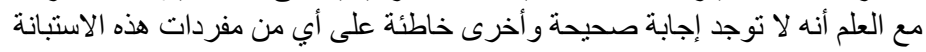

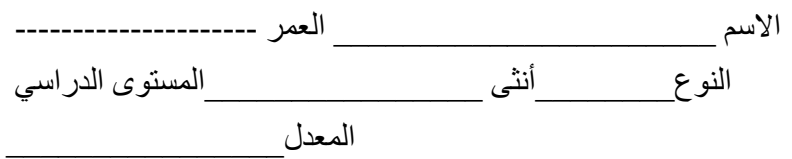




\begin{tabular}{|c|c|c|c|c|c|c|}
\hline دائما & عادة & 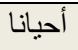 & غالبا & أبدا & 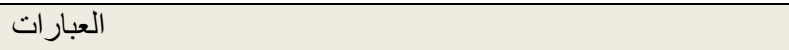 & \\
\hline & & & & & الاستر اتيجيات العامة للقر اءة & \\
\hline & & & & & أضع لنفسي هدفا عندما أقر أ. & 1 \\
\hline & & & & & أفكر فيما أعرف ليساعدنى فى فهم ما أقر أ. & 3 \\
\hline & & & & & القى نظرة عامة على النص قبل قر اعته لمعرفة ما يدور حوله النص. & 4 \\
\hline & & & & & أفكر عما إذا كان محتوى النص يناسب هدف قراءتي. & 6 \\
\hline & & & & & عند القراءة أقرر ماذا سوف اركز عليه وماذا سوف اتركه. & 9 \\
\hline & & & & & أستخدم الدلائل التى وردت فى السياق لتساعنى على فهم أفضل لما أقر أ. & 12 \\
\hline & & & & & أقوم بالتحليل النقدى و التقييم للمعلومات الموجودة فى النص. & 14 \\
\hline & & & & & أختبر فهمي عندما أقابل معلومات جديدة. & 16 \\
\hline & & & & & أحاول أن أخمن عما يدور محتوى النص عندما أقر أ. & 17 \\
\hline & & & & & استر اتيجيات حل المشكلات & \\
\hline & & & & & أقرأ ببطء وبعناية لكى أتأكد من أننى أفهم ما أقرأ. & 7 \\
\hline & & & & & أحاول العودة للمسار الصحيح عندما أفقد التركيز. & 8 \\
\hline & & & & & عندما يصبح النص صعباً ، إلنتى اركز بثدة على ما أقراً. & 10 \\
\hline & & & & & أنتوقف من فترة الى فنرة و أفكر فيما أقر أ. & 11 \\
\hline & & & & & عندما يصبح النص صعبا، أقوم بإعادة قر اءته ليزداد فهمى. & 18 \\
\hline & & & & & الاستر اتيجيات المساندة للقر اءة & \\
\hline & & & & & أثناء القراءة ، أقوم بتدوين ملحوظات لتساعدني فى فهم ما أقرأ. & 2 \\
\hline & & & & & عندما يكون النص صعبا ، أقر أ بصوت مرتفع ليساعدنى أن أفهم ما أقر أ. & 5 \\
\hline & & & & & أعيد صياغة ما ورد فى النص من أفكار بأسلوبى لفهم أفضل لما أقر أ. & 13 \\
\hline & & & & & أجول وأصول فى النص لأجد رو ابط بين الافكار & 15 \\
\hline & & & & & أثثاء القر اءة اترجم من اللغة الانجليزية الى العربية. & 19 \\
\hline & & & & & أثثاء القراءة أفكر فى المعلومات باللغة الانجليزية والعربية معاً. & 20 \\
\hline
\end{tabular}

\section{Appendix C}

Reading Comprehension Test

\section{Zookeepers}

Who takes care of the animals in a zoo? The zookeepers, of course! You must be willing to work hard and have a love of animals to do this job. Animals, from huge elephants to tiny birds, need a lot of care. The first thing every morning, all the animals are checked. Do any of them look hurt or sick? Watching the animals is an important part of the zookeeper's job. Changes in the way an animal acts might mean something is wrong. Then the zoo's animal doctor, the veterinarian, should be called.

A keeper must also clean the animals' area. Usually the keeper sprays the area with a hose. The keeper also orders food every day from the zoo kitchens. Buckets of fish, meat, fruit and vegetables, seeds, eggs and grains are measured, chopped, and fed to the animals. A keeper gets to know the animals well. Will the gorilla take a pill hidden inside a grape, or must the medicine be mixed in sugar water? The keeper knows. Someone has to be the jobs every day, for animals need care even on holidays. Zookeepers know the animals they care for are important.

1) Read the passage and choose the correct answer.

1. Another good title for this story is 
a. "Feeding the animals" b. "Work for animals lovers"

c. "Going to the zoo" d. "The best animal"

2. The writer thinks that zookeepers are
a. lazy
b. weak
c. mean
d. hard-working

3. This story was written in order to

a. give directions $\quad$ b. list some rules $\quad$ c. teach about a place $\quad d$. tell about a job

4. What is the first thing a zookeeper must do each day?

a. feed the animals b. look at the animals

c. clean the living area d. give medicine to sick animals

5. Why does the writer tell about the gorillas?

a. to show the gorillas are dangerous b. to show the zookeepers are kind

c. to show the zookeepers know the animals well d. to tell what gorillas eat.

6. You can tell that a veterinarian is the zoo's

a. owner b. keeper c. painter d. doctor

7. All animals need a lot of

a. care b. cloths c. glasses d. hotels

8. The keeper sprays the area of the animals with a

a. hose b. perfume c. cola d. tea

9. Animals need care

a. all the time b. two days a week

c. on holidays d. five days a week.

Emma and the old house

Ever since Emma could remember, the old house next door had been empty. Panted peeled from it, and its front steps sagged. No car ever parked in its driveway. No family ever laughed inside. Emma's friends called the house spooky! Creepy! A wreck! But Emma didn't. She could see the house from her bedroom window. Every night before she went to bed looked at it. She saw moonlight shine on its dark windows, and she felt sorry about the old house. She wished there were something she could do. "I wish someone would fix up that old house. I wish they would return it into the brightest, happiest house on the street! Emma climbed into bed and went to sleep. One morning Emma heard a rumbling noise. It was coming from the street. Emma slid out of bed and ran to her window. A large green truck rumbled past her house. It stopped next door. People wearing work clothes got out of the truck. They carried carpenters' tools. They climbed the old house's sagging steps and disappeared inside.

She heard the sound of a hammer. She heard the sound of a power saw. She heard an electric drill. What's going on? Thought Emma. Emma watched three people wearing white coveralls out of a van. They carried ladders and buckets of paint. "Are you going to paint that house?" called Emma. Yes, we are going to turn this old house into the brightest, happiest house on the street. Emma remembered her wish and said sometimes wishes do come true!

2) Read the story and choose the correct answer.

10. Emma wished that

a. the old house did not look scary $\quad$ b. her family could move

c. her family could buy the house d. someone would fix up the old house

11. Why Emma feel sorry about the old house?

a. It was creepy b. No one cared about it

c. It was next door to her house d. Its windows were dark

12. Who were the people in coveralls?
a. Thieves
b. Painters
c. Emma's friends
d. The new owners 
13. The rumbling noise Emma heard was made by a
a. saw
b. hammer
c. truck
d. drill

14. What will happen next?

a. Emma will live in the old house b. The old house will be torn down

c. A new family will move into the old house.

d. Emma will feel sorry about the old house.

15. Emma could see the house from her

a. school b. bedroom window c. door d. garden

16. Who called the house spooky! Creepy! A wreck!
a. Emma's parents
b. Emma's friends
c. Emma's sister
d. Emma's brother

17. The workers carried ladders and buckets

a. of paint b. of ice-cream c. of tea d. of water

\section{Copyrights}

Copyright for this article is retained by the author(s), with first publication rights granted to the journal.

This is an open-access article distributed under the terms and conditions of the Creative Commons Attribution license (http://creativecommons.org/licenses/by/3.0/). 